\title{
"Italians First": Workers on the Right Amidst Old and New Populisms
}

\author{
Gilda Zazzara \\ Ca' Foscari University of Venice
}

\begin{abstract}
This article deals with the Italian working-class attitude to vote right-wing, seen in a long-term perspective, in particular in the northern and more industrialized regions. It stresses the fact that the left-wing parties reached their largest majority among working-class voters only for a short period. The end of the long cycle of factory conflicts of the 1970s on the one side, and the crisis of the "local political subcultures"-Catholic and Communist-in mediating the relationship between the working class and the central State on the other, marked the outbreak of a new political phenomenon: the establishment of the Lega Nord party in the 1980s. This party has been able to shift progressively from identity-based claims and secessionist proposals to xenophobia and the demand that a priority be accorded to Italian workers on the labour market. In the most recent years workers' support for the Lega Nord has been contended by a new populist competitor, the Five Star Movement, whose ability to intercept a widespread "working-class malaise" will be tested in years to come.
\end{abstract}

\section{Workers (of the North) on the Right}

It is no longer a secret or taboo: in the new millennium, when northern Italian workers go to the polls - the majority of the country's five million industrial and construction workers are concentrated there - they vote for right-wing parties. ${ }^{1}$ Perhaps due to a naive understanding of class voting, or the steadfast memory of a once strong labor movement (the Italian working-class struggle was exceptional both in its political engagement and sheer persistence), this issue has almost always been perceived in terms of "abandonment," if not an outright "betrayal" of the Left.

Whether the workers betrayed the Left or vice versa, the fact remains that in recent years the grass roots of the Center Left and its principal party, the Partito Democratico (PD), are found among the public sector (a particular stronghold being teachers) rather than the self-employed; white-collar rather than blue-collar workers; pensioners rather than those who are still employed; but above all, more in the Center and South of the country than in the North. In particular, the working-class vote seems to be split along a territorial divide: The workers in the northern regions (Lombardy and Veneto first and foremost), where the industrial working class was concentrated, now vote mostly for right-wing parties.

But which Right has managed to grasp a significant slice of the workingclass vote? As we will see better below, the working-class right-wing party in 
Italy has been the Lega Nord (LN); one of its leading exponents went so far as to define it "the new labour party." 2 Founded on local concerns, ethnic and identity-based claims, and secessionist proposals, LN is a right-wing populist, but not fascist, party. ${ }^{3}$ In more recent years it has shifted its position toward issues of sovereignty, centred on violent controversy against immigration, European austerity policies, fiscal pressure, and the universal welfare state. In this way, LN has managed to tap into the apprehensions of all the social groups impoverished and disadvantaged by the economic crisis and globalization.

In the past, there had also been some working-class consensus towards Forza Italia (FI), the personal political party established by entrepreneur Silvio Berlusconi. However, despite efforts to validate an "Italian dream" of social mobility and "the self-made man," Berlusconi has always been viewed by the working class as an employer, thus not to be trusted completely. Of less importance - at least in the North - have been the parties to Berlusconi's right, even when they harken back to the traditions of social fascism.

Recently, the Neo-Fascist party Casa Pound Italia (CPI) has sought visibility and consensus among workers by siding with them in some local protests against industrial closures and restructuring. One such episode was in Terni, a small town in central Italy, home to one of the largest public steelworks in Italy-privatised during the 1990s, and eventually sold to the multinational ThyssenKrupp. ${ }^{4}$ In 2014, ThyssenKrupp announced it was laying off five hundred workers. CPI attempted to join the protest with the slogan "Nationalise the Terni steelworks," but failed to establish a true relationship with the workers. ${ }^{5}$ Indeed their action led to widespread anti-fascist protests in the town. ${ }^{6}$

Nonetheless, a mere analysis of voting and party policies would hardly constitute an exhaustive exploration of this rightward shift among industrial workers and the working class more generally: It is indeed difficult to position populist movements along the traditional right-left axis or to interpret rising abstention from voting - after years of exceptional turnouts, the gap between Italy and the majority of European countries has narrowed. ${ }^{7}$

More recent qualitative analyses paint a picture of widespread "workingclass malaise" fuelled by a mixture of factors both material (growing job insecurity, economic impoverishment, loss of rights) and cultural (depreciation of manual labor, erosion of working-class identity, the disappearance of forms of class sociality). The profile of the typical Italian worker, especially younger workers, is characterised by feelings of apathy, solitude, fear, and frustration. One investigative journalist revealed widespread use of narcotics among workers, which was a response to this personal anxiety, but also a means of maintaining the standards of productivity demanded by employers. ${ }^{8}$. Since the global financial crisis there have been several cases of suicide among despairing job seekers. ${ }^{9}$

The deterioration in human relations and solidarity in the workplace can be seen firstly in the mistrust, if not open hostility, expressed towards immigrant 
workers - more recently their identity has become confused with that of the refugees disembarking daily on the coast of Sicily. Factories with high numbers of foreign workers witness a mixture of "social passivity, widespread individualistic behaviour and unquestioning acceptance of working conditions.",

While overall trade union membership has increased, thanks to pensioners and public sector employees, there has been a clear fall in membership among industrial workers. ${ }^{11}$ Though workers turn more and more to the unions for fiscal, legal, and social security services, their engagement in matters related to policy and negotiation have receded. A survey carried out in 2006 by the Confederazione generale italiana del lavoro (CGIL), the principal left-wing union in Italy, registered overwhelming right-wing leanings among workers in the North as well as clear preferences for unions without political affiliations, but with a more collaborative approach towards employers. ${ }^{12}$ It seems that it is precisely politics that has lost its appeal among workers, even among those communities that have been involved in conflicts or protests - often carried out in open disagreement with trade unions. ${ }^{13}$ It seems possible today to fight for acquired rights or job security without investing in the struggle with values that goes beyond the immediate circumstances.

\section{The Italian Case}

If northern Italian workers vote mostly for the Right and prefer apolitical trade unions, what can we say has become of the Italian case? During the 1960s and 1970s, Italy was the scene of a series of labor struggles that were among the most militant and tenacious in the West. The strongly politicized Italian trade union movement had an exceptional capacity for mass mobilization. The key position of workers and the authority exerted by wage earners were cornerstones of the political discourse both for the historical Left-whether Communist or Socialist-and the vast constellation of the "New Left." However, Italy was never a "nation of workers" like Great Britain or Germany. Industrial development occurred late, developed quickly, and was subsidized but spread unevenly across the territory. The workers' movement and socialism started in the countryside, among share-croppers and farm laborers, and with decidedly local connotations and a strong avant-garde intellectual component. In the very apt words of one communist historian: "ideas (in Italy) came faster than machines and capital." 14

An important role in the development of the workers' movement was played by the imbalance between the North-where the first industries were established and the first entrepreneurial capitals were created-and the extended southern reaches of the country - plagued by an economy based on large agricultural estates, political corruption, and organized crime. Addressing his fellow Communists Antonio Gramsci had already identified the "southern issue" as "one of the fundamental policy problems facing the nation's revolutionary proletariat" 15 - for decades it remained a non-negotiable cornerstone of Italian trade union policy. ${ }^{16}$ Between the two world wars, 
authoritarian modernization under fascism consolidated the industrial monopoly of the North West (the so-called "industrial triangle") and interventions of the State in the economy. Smaller communities of skilled, industrial urban proletariat continued to live alongside larger groups of workers who fluctuated between agriculture and industry, including a large and fragmented subordinate female proletariat. ${ }^{17}$ Despite the corporate regulations and welfare measures introduced by the regime, working conditions continued to be precarious and underdeveloped.

In the wake of the Second World War, Italy undertook an exceptional drive towards political and social restitution, yet failed, nonetheless, to redress its huge internal territorial fracture. During the 1960s, millions of young people emigrated from the South to the "industrial triangle," to the factories of Milan, Genoa, and Turin where they discovered the political and trade union tradition of the pre-fascist generations, and brought new life into the struggle for better conditions and wages. This social and cross-regional mobilization gave rise to great upheavals towards the end of the decade, involving the establishment of work councils, the renewal of the principal collective contracts, and the Worker's Statute, a law that granted formidable recognition to the trade union movement. The workers took their action from the factories into society, making a fundamental contribution to the country's most important social reforms, on the basis of principles enshrined in the 1948 Constitution, which had, till that point, remained largely unenforced. ${ }^{18}$

In just a few years, the working class benefited from a huge redistribution of wealth and social mobility. ${ }^{19}$ Between 1968 and 1976 (peaking in the 1972 elections), the left-wing parties-Communist and Socialist-reached their highest consensus and their largest majority among working-class voters. This was a short parenthesis however: In the history of the Italian Republic, from 1945 onward, the workers of the North never yielded a majority to the Left. ${ }^{20}$ During the 1950s, the stronghold of the Partito Comunista Italiano (PCI) was in the countryside, which was undergoing a transformation towards a capitalist economy, and among the urban middle class, in particular in the central regions (Emilia-Romagna and Tuscany). ${ }^{21}$

In the political arena, the Left's formidable opponent was the conservative, multiclass, Catholic Democrazia Cristiana (DC). The DC had forged a hegemonic consensus founded on the religious divide and widespread subsidized and socially protected development (summed up in the slogan "One Factory Per Bell-tower"). Thus, local and cultural affiliation, together with class, contributed to the creation of a two-colored map, with the country divided into areas and cities that were either red or white. Two mass parties-PCI and DC-contended popular consensus mediating on a central position for long-term "local political subcultures." 22

In the areas dominated by large Fordist factories, the left-wing parties had an advantage, but already from the 1970s onward, under the weight of economic crisis, restructuring and the decline of industry, this foothold began to crumble. Meanwhile, industry began to decline in favor of services. Already in 1977, the 
tertiary workforce had overtaken the secondary: After its short trajectory, the age of "working-class centrality" was drawing to a close.

These changes affected not only the professional profile of the workforce, but also the country's industrial makeup, with a sudden fall in the numbers working in large factories and a parallel boom in blue collar workers in small to medium businesses. This was the result, on the one hand, of decentralization processes and, on the other, of pre-existing manufacturing traditions. Sociologists and political scientists began to identify a "Third Italy" - coinciding with some regions in the Centre and the North East - that had seemed invisible in the traditional North-South interpretation. ${ }^{23}$ This "Third Italy" had a completely different work culture than the large factories. Among other things, workers there were willing to work long hours, they aspired to purchase consumer goods (to become home owners first and foremost), and to become self-employed. While formally they were paid less than the workers in large factories, they often supplemented their income with substantial cash-in-hand remuneration. Though not averse or hostile toward trade unions, they did have specific needs. They were more interested in individual salaries, mobility, flexibility, services, and collaboration rather than working conditions, political representation, negotiation, or class struggle.

While this world of workers was quietly expanding, the other was crumbling steadily. The failure of industrial action at the Fiat plant in Turin, which ended in twenty thousand workers being put on a redundancy scheme, was the prelude to an endless series of reorganizations among the major Italian industrial groups. It continued with a collapse in trade union unity (one of the most significant political achievements of the 1960s and 1970s), which occurred during the reform of an index designed to protect salaries from inflation (the so-called scala mobile). In 1985, the PCI suffered a resounding defeat in a referendum aimed at blocking this reform, which was being promoted by a socialist government intent on normalizing industrial relations and pursuing a policy of capitalist modernization.

Quite suddenly, the atmosphere changed in Italian factories and among workers. Travelling through the factories and residential quarters of the Fiat workers in 1988, the journalist Gad Lerner gave a voice to a world of disorientated men, workers who, within a few years, had gone from seeing themselves at the forefront of a political revolution to feeling like social refuse. In particular, meeting the inhabitants of Mirafiori Sud, Turin's signature working-class area, Lerner became painfully aware of "the definitive dissolution of any form of working-class identity." 24 As it was too early for that sense of loss to be collectively processed or publicly voiced, the workers' path out of working-class identity took underground routes, which could only be understood and explained in hindsight.

\section{Lega Nord}

LN was born in 1989 with the fusion of two regional movements: one from Veneto (Liga Veneta: using liga, which is lega in Veneto dialect) and one 
from Lombardy (Lega Lombarda). The Veneto region was the birthplace of the movement. ${ }^{25}$ A mainly agricultural region and source of emigration since the unification of Italy, Veneto had been defined as the "South of the North." The Catholic Church's widespread network across the region and the overwhelming hegemony of the Catholic party (after the war in some municipalities, the DC won eighty percent of the votes) earned Veneto the label "the Vandée of Italy.",26

During the 1970s, this backward Veneto underwent extraordinary development thanks to an economy of small and medium businesses. Through hard work and the support of family networks, many farmers and workers were able to become entrepreneurs. Small and medium businesses were not exempt from the influence of the growing trade union movement; in industrialized rural areas, competition was intense between the two major unions, the red CGIL and the white Confederazione Italiana Sindacati Lavoratori (CISL). ${ }^{27}$ Though CGIL gained ground in Veneto, it had little effect on the political dominance of the DC. The only exceptions were the southernmost province (Rovigo), a typically red area of left-wing farm laborers, and the huge industrial area of Porto Marghera (Venice). The part of the region with the highest level of moderate clerical consensus (i.e., political consensus towards DC and the Church in general) - the upper part of the plain of the Po river valley and the foothills of the Alps, the so-called "Pedemontana" - was also the area with the highest concentration of small-scale industry.

Liga Veneta was founded in 1980 and, surprisingly, after three years it won three seats in the parliament. Even areas with a high concentration of workers and with a significant socialist and trade union tradition, like Schio, a factory town near Vicenza and the birthplace of the textile industry, showed support for this small political party.

In their very first election manifesto, after a call for political independence, the second point put forward by Liga Veneta was "precedence to be given to Veneto-born workers in the work place and in social services." 28 At that time, local people in Veneto did not see non-EU workers as a threat, instead it was southern Italians who found jobs, not so much in industry but in the public sector and particularly in schools. By claiming a priority, Liga Veneta was giving a voice to popular anti-southern sentiments. Persistent anti-state prejudice was being projected on the South. ${ }^{29}$ In Liga Veneta propaganda, southern Italians were described as lazy, unproductive, and used to expecting benefits. This image found particular support among the workers of small and medium enterprises, who were accustomed to working longer and harder than normal labor contracts, to mobility on the labor market and who were less influenced by union policies of public support for the economic development of the South.

A decisive turning point was the devastating earthquake that hit some southern regions in the autumn of 1980. Many workers from the North, including Veneto, joined the effort to bring aid to the stricken population. Some of these returned feeling disappointed by the passive and fatalist attitude they encountered among the local population. They compared the inefficiency they 
perceived to the Northern region of Friuli, which had been struck by an equally strong earthquake just four years earlier. ${ }^{30}$ During the 1980 s graffiti began to appear, even in strongly working class and unionised areas, calling for an eruption of Mount Etna in Sicily. During the early days of Liga Veneta, a poor man's movement born among the lower levels of society, these graffiti were an important tool of political propaganda.

\section{The Trade Unions}

The transformation in the world of labor during the 1980s (widespread industrialization, crises in large industry, outsourcing, and internationalized markets) drove a wedge between workers and the traditional political parties. This became evident in the virulent economic and institutional crisis that exploded at the beginning of the 1990s. In rapid succession, Italy suffered a dramatic financial crisis, the greatest corruption scandal in its history (the so-called "clean hands" investigation), the changeover to a majority electoral system and the disappearance of the republic's major, historical political parties. DC and the Partito Socialista Italiano (PSI) were crushed under the weight of judicial investigation, while, after the fall of the Berlin Wall, PCI decided on its own dissolution and abandoned its ties to communist ideology. Large public enterprises were liquidated and serious restructuring and privatization plans began to come into effect. Between 1992 and 1993, the unions, the government, and employers' associations established broad framework agreements on labor. Wage restraints were set to reduce inflation, new representation systems were established in the workplace, and contract negotiations became subordinate to productivity and competitiveness.

Within the context of this system in crisis - which is often referred to as the beginning of the Second Italian Republic - new political phenomena appeared: Silvio Berlusconi's political party and the extraordinary adventures of LN. In the last elections of the First Republic, LN achieved amazing results in Lombardy (twenty-three percent) and Veneto (twenty-six percent, including other groups that supported autonomy). On the Left, this success was interpreted as a protest against the State led by small entrepreneurs, the selfish resentment of the rich, "a mass withdrawal from the State led by the very middle class that was traditionally the foundation of consensus." 31 That workers might have given their vote to LN was hardly considered, despite clear signals that this was indeed happening. In 1992, for example, in an area of Veneto with a strong working-class tradition (Conegliano, home of Zoppas, one of Italy's largest electrical appliance manufacturers), the Center-Left candidate Franco Bentivogli, an important trade union leader, was solidly defeated by the LN candidate who was preferred by many of Bentivogli's own workers. ${ }^{32}$

It was during this period that the first non-EU immigrants began to replace the terroni (a derogative term used to describe workers from the South) as catalysts to fuel fears among groups who felt threatened by change. LN managed to acquire an identity as a party for the people, far from the halls of power and 
willing to provide protection from the ever-growing fear of foreign criminality. The party presented itself as the voice of local producers, entrepreneurs, and workers, who, as we have seen, in the world of small businesses were fluid categories and bled into each other. The slogan "People of Veneto First" (which today has become "Italians first") began to be thought of as plain common sense among many workers, and even among many grass roots union representatives. LN even tried to set up its own union (SINPA, the union of the Po Valley), but failed: Workers stayed faithful to their traditional organizations, which were better equipped and more effective in representing them.

Activists in the union CISL were the first to adopt the opinions expressed by LN and they were gradually followed by CGIL. ${ }^{33}$ Many workers voted LN though they still retained membership of left-wing trade unions, much as they had done in the past with DC. They continued, in other words, to find no contradiction in being part of a trade union movement, even engaging in conflicts on the factory floor, while remaining politically conservative. ${ }^{34}$

The extent to which LN's discourse - "the Veneto people first" and now "Italians first" - has also infected CGIL can be understood from the surprising appeal made by a senior union figure, who called on entrepreneurs in the footwear industry to hire Italian workers because they worked harder and were more adept at defending wage levels. ${ }^{35}$ This statement - which met with scant protest from the union as a whole - is a sign of how far the ethos of LN has spread and shows how the issue of workers' consensus with right-wing populism goes beyond the ballot box; it has become a broader issue, related to the evolution, amidst persistence and repression, of working-class culture. Furthermore, LN has even broken the last stronghold of the Left and the working-class vote: the so-called "red" regions of Central Italy. ${ }^{36}$

\section{A Changing Scenario}

The last general election took place in February 2013. ${ }^{37}$ The great novelty was an exceptional twenty-five percent won by the Movimento Cinque Stelle (M5S), a party founded in 2009 by the comedian and actor Beppe Grillo, the movement had grown out of Grillo's personal blog. M5S might be defined as the masterpiece of the Italian populist laboratory. It is particularly difficult to position along the classic left-right axis - both due to the eclectic ideological mix professed by its executive group and to the heterogeneous make-up of its grass roots.

For LN, the 2013 elections were something of a meltdown: On a national level, the party fell from 8.3 to 4.1 percent, but the decline was even greater in areas where its historical roots were deepest, such as the Veneto. It is legitimate to presume that the LN vote shifted toward M5S. ${ }^{38}$ A foretaste of this shift had already been seen the previous year when the first M5S mayor was elected in a tiny Veneto municipality where LN had previously enjoyed very strong support (Sarego, in the province of Vicenza). The LN candidate was beaten by a slim majority. ${ }^{39}$ Since then, M5S has won many of the larger cities including 
the capital (for many years referred to as "Rome the robber" in LN propaganda, a symbol of all the country's woes), and it now openly campaigns to govern the country after the 2018 elections.

Alongside its attacks on politics, bureaucracy, and finance, M5S is now putting forward concrete proposals regarding employment. Its analysis starts from the premise that industrial society has had its day and that work in the future will be, for the most part, immaterial, intellectual, robotic, digital, and, above all, there will not be enough to go around. Its first answer would be a "basic income" for the unemployed and for citizens who live below the poverty line, as well as wage integration to increase pay for underpaid workers. Recently M5S commissioned a provisional study on work projected over the next ten years from Domenico De Masi, a retired Professor of the Sociology of Work. De Masi's strange solution consists of a reduction of overall working hours, to be achieved by having the unemployed work for free. This, in his opinion, would change the labor market to such an extent as to inevitably force a more equitable redistribution of employment. ${ }^{40}$ The unemployed would offer their skills through an online platform, unleashing "brutal competition that would break the labour market and thus force the unions to come to the negotiation table and agree to have the 23 million employed give over 10 percent of their hours to the 3.1 million unemployed." ${ }^{41}$ It is evident that this is an impracticable proposal, and it has already been met with widespread criticism among experts; it also illustrates the provocative and demagogic approach M5S takes to social issues.

Even if Grillo's party seems to be more attractive to the unemployed and post-industrial workers, including the "second-generation self-employed" 42 who are precariously poised today between the middle and working classes and make up the backbone of M5S activists, we still need to ask why the party has become palatable to blue-collar workers. This fact has emerged from various polls, and it is also perceived by people who are with them in the front line, such as former CGIL's national secretary for mechanics, Maurizio Landini. ${ }^{43}$ Workers "on the shop floor follow the union, but then, they vote Grillo," despite the fact that M5S is not organized in the workplace. ${ }^{44}$ There is no doubt that the workers' sympathy for M5S also involves some aspects of an antibureaucracy protest, which also targets union leaders. Indeed, it could be that a large number of workers are convinced - in Grillo's words - that "class struggle has been substituted by caste struggle, or better, by a struggle between those who produce wealth and social services, and a parasitic class, the castes." 45

However, we are left to wonder if the working-class vote yet again, or even more than ever, will reward a (demagogic) claim to protect the labor market from foreign competition. The most recent local elections held in Monfalcone (Trieste) suggest that this is a possible outcome. Monfalcone is known as the "Italian Danzig" as it has one of the largest shipbuilding industries in Europe. The management of Fincantieri sing the praises of its "reverse delocalization" model in which hundreds of outsourced companies, many registered abroad with contracts signed in foreign countries, employ one thousand Italian 
workers alongside five thousand foreigners, the majority of whom come from Bangladesh. This model allows for an exceptional reduction in the cost of labor and record productivity.

Though it is a city with a long socialist and trade union tradition, in 2016, Monfalcone elected a LN mayor, and it is the first time since the birth of the Italian Republic that the city has had a right-wing mayor. No doubt the presence of foreign workers in the shipyard played a role in this result and led to sentiments that work ought to be given "to our workers first." Many of these workers see no contradiction between this demand and the classic left-wing battles for job security and a dignified wage since they are at risk from what they perceive as unfair foreign competition.

We might be inclined to say that in Monfalcone class struggle has won over Grillo's "caste struggle" against the parasitic elites; unfortunately, however, it has been an internal class struggle: local workers against global workers. The early LN slogan "Terroni Out" widely used in the heyday of Italian industrialization has now been replaced during the current crisis by the more updated "Stop Bangla."

The Monfalcone shipyard was one of many stops in another, more recent journey undertaken by Gad Lerner among Italian workers - a television investigation broadcast by the public television service in a time slot that guaranteed the smallest possible number of viewers. ${ }^{46}$ In the canteen at Fincantieri, Lerner interviewed a worker who is also a municipal councillor for LN: In the factory, he calls for precedence for Italian workers, while in the local constituency he fights against accepting refugees. Meanwhile, the voices of workers on their break can be heard in the background, a babel of languages that no longer defines class identity, solidarity, or egalitarianism.

Lerner's new report began in Turin, the same place he had conducted his investigation thirty years earlier. ${ }^{47}$ Fiat Mirafiori, which at that time was still the largest factory in Italy, is now a highly automated plant with three thousand workers employed by the multinational Fiat Chrysler Automobiles (FCA). In 2011, a referendum was held that was excruciating for the trade union movement: The workers chose to accept a new system of labor organization in the plant known as World Class Manufacturing (WCM) to ensure that the factory would continue operating. ${ }^{48}$ Lerner had dinner with a working class family that is certain that red flags will never fly again above the factory gates; they declared greater faith in Sergio Marchionne, the CEO of FCA, than in Maurizio Landini, the secretary of the CGIL mechanics union at that time.

The Italian working class seems poised between two poles. Horizontally there is a struggle for employment pitting the poor against the poor. Vertically there is a voluntary acceptance of capitalist strategies and their hidden forms of submission. However, Lerner's journey also shows the many new faces, cultures, and professions that make up the working class today, especially in the fields of services, logistics, and communications. To counter the Italian workers' decline into xenophobia, chauvinism, and populism, or toward the most abject corporate subservience, it is necessary to redefine the 
confines of the class that works to live. It exists, grows, and thinks about its living and working conditions, even without political representation, often despising party politics. The author of this article feels that the trade unions alone today have the resources and the network of social connections to avoid these wayward paths.

\section{NOTES}

1. Paolo Feltrin, "Le scelte elettorali dell'ultimo quinquennio: voto di classe e voto degli iscritti al sindacato," Quaderni di Rassegna Sindacale 4 (2010): 83-109; Paolo Feltrin/Id., "Basi sociali e tendenze territoriali alle elezioni politiche," Italianieuropei 3 (2006), https://www.italianieuropei.it/it/la-rivista/archivio-della-rivista/item/979-basi-sociali-e-tendenze-territoriali-alleelezioni-politiche.html (Accessed on March 27, 2018).

2. Antonella Benenzato, "Un operaio su due vota Lega. Zaia: Siamo i nuovi laburisti," Il Giornale di Vicenza, April 20, 2010, http://www.ilgiornaledivicenza.it/home/veneto/un-operaiosu-due-vota-lega-zaia-siamo-i-nuovi-laburisti-1.1207135 (Accessed on July 10, 2017). (Il Giornale di Vicenza is a daily newspaper).

3. Andrej Zaslove, The Re-invention of the European Radical Right. Populism, Regionalism, and the Italian Lega Nord (Montreal, 2011).

4. Alessandro Portelli, La città dell'acciaio. Due secoli di storia operaia (Rome, 2017).

5. Casapounditalia.org, Casa Pound, "blitz" sotto palazzo Chigi per chiedere nazionalizzazione acciaierie Terni, October 16, 2014, http://www.casapounditalia.org/2014/10/casapoundblitz-sotto-palazzo-chigi-per.html (Accessed on July 20, 2017).

6. Infoaut.org, Terni è antifascista! Respinta Casa Pound, February 17, 2014, http://www. infoaut.org/antifascismonuove-destre/terni-e-antifascista-respinta-casa-pound (Accessed on July 20, 2017).

7. Maurizio Cerruto, "La partecipazione elettorale in Italia," Quaderni di Sociologia 60 (2012): 17-39.

8. Loris Campetti, "Quanto "tira" la classe operaia"; "Sata di Melfi, dal "prato verde" alla tossicodipendenza"; "Tra fatica e coca, operai alla catena"; "Senza la speranza vince la cocaina”, il manifesto, May 14, 16, 23, 27, 2008. (il manifesto-written in small letters-is a daily newspaper).

9. Antonio Sciotto, Sempre più blu. Operai nell'Italia della grande crisi (Rome-Bari, 2011).

10. Vladimiro Soli, Lavorare in AIA. Soggettività operaia, immigrazione e governo del lavoro. Rapporto di ricerca a cura dell'IRES e della FLAI-CGIL del Veneto (Venice, 2017), 52.

11. Mimmo Carrieri and Paolo Feltrin, Al bivio. Lavoro, sindacato e rappresentanza nell'Italia d'oggi (Rome, 2016).

12. Agostino Megale, ed., Lavoro, politica e sindacato. Come hanno votato i lavoratori alle elezioni politiche dell'aprile 2006 (Rome, 2008). 2010).

13. Matteo Gaddi, Lotte operaie nella crisi. Materiali di analisi e di inchiesta sociale (Milan,

14. Gastone Manacorda, Il movimento operaio italiano attraverso i suoi congressi. Dalle origini alla formazione del Partito socialista (1853-1892) (Rome, 1963, I ed. 1953), 44.

15. Antonio Gramsci, "Alcuni temi della quistione meridionale" (I ed. 1926), in Antonio Gramsci/Id., La questione meridionale, eds. Franco De Felice and Valentino Parlato (Rome, 1973, I ed. 1966), 131-60, 134.

16. Filippo Sbrana, "Dalle lotte unitarie al leghismo: sindacati e lavoratori di fronte al dualismo Nord-Sud," Mondo contemporaneo 2 (2016): 87-137.

17. Musso Stefano, ed., Operai (Turin, 2006). 1992).

18. Aris Accornero, La parabola del sindacato. Ascesa e declino di una cultura (Bologna,

19. Luciano Gallino, La lotta di classe dopo la lotta di classe, Interview edited by Paola Borgna (Rome-Bari, 2012).

20. Salvo Leonardi, "Il voto operaio in Italia: declino o continuità?," Quaderni di Rassegna Sindacale 4 (2006): 83-127. 
21. Fausto Anderlini, Il voto, la terra, i detriti. Fratture sociali ed elettorali dall'alba del 2 giugno al tramonto del 25 febbraio 2013 (Bologna, 2013).

22. Carlo Trigilia, Le subculture politiche territoriali (Milan, 1981).

23. Arnaldo Bagnasco, Tre Italie. La problematica territoriale dello sviluppo italiano (Bologna, 1977).

24. Gad Lerner, Operai. Viaggio all'interno della Fiat. La vita, le case, le fabbriche di una classe che non c'è più (Milan, 1988), 179.

25. Francesco Jori, Dalla Liga alla Lega. Storia, movimenti, protagonisti (Venice, 2009); Anna Cento Bull and Mark Gilbert, The Lega Nord and the Northern Question in Italian Politics (Basingstoke, 2001).

26. Ilvo Diamanti and Gianni Riccamboni, La parabola del voto bianco. Elezioni e società in Veneto (1946-1992) (Vicenza, 1992).

27. Fausto Anderlini and Cesco Chinello, eds., Operai e scelte politiche. Il caso delle zone bianche a economia diffusa del Veneto (Milan, 1986).

28. Presentazione e programma della Liga Veneta (Padua, 1980).

29. Antonino De Francesco, La palla al piede. Una storia del pregiudizio antimeridionale (Milan, 2012). 1994).

30. Giovanni De Luna, ed., Figli di un benessere minore. La Lega 1979-1993 (Florence,

31. Marco Revelli, Le due destre. Le derive politiche del postfordismo (Turin, 1996), 33.

32. On the history of the Zoppas see Graziano Merotto, La fabbrica rovesciata. Comunità e classi nei circuiti dell'elettrodomestico (Rome, 2015); Paolo Feltrin and Adriano Miolli, La scoperta dell'antagonismo. Gli anni '60 alla Zoppas: operai, lotte, organizzazione (Venice, 1981).

33. Roberto Biorcio, La rivincita del Nord. La Lega dalla contestazione al governo (Rome-Bari, 2010).

34. Alessandro Casellato and Gilda Zazzara, eds., Veneto agro. Operai e sindacato alla prova del leghismo (1980-2010) (Venice-Treviso, 2010).

35. Alessandro Abbadir, Cgil: "Ora i calzaturieri assumano operai italiani," La Nuova Venezia, January 9, 2015, http://nuovavenezia.gelocal.it/venezia/cronaca/2015/01/09/news/cgilora-i-calzaturieri-assumano-operai-italiani-1.10640206 (Accessed on July 25, 2017). (La Nuova Venezia is a daily newspaper).

36. Gianluca Passarelli and Dario Tuorto, Lega \& Padania. Storie e luoghi delle camicie verdi (Bologna, 2012).

37. Italian National Election Studies (ITANES), Voto amaro. Disincanto e crisi economica nelle elezioni del 2013 (Bologna, 2013).

38. Ilvo Diamanti, Un salto nel voto. Ritratto politico dell'Italia di oggi (Rome-Bari, 2013).

39. Paolo Stefanini, "Il primo sindaco grillino: Con me inizia la terza Repubblica," Linkiesta.it, May 7, 2012, http://www.linkiesta.it/it/article/2012/05/07/il-primo-sindaco-grillinocon-me-inizia-la-terza-repubblica/6976/ (Accessed on July 20, 2017).

40. Domenico De Masi, Lavorare gratis, lavorare tutti. Perché il futuro è dei disoccupati (Milan, 2017).

41. Antonio Sciotto, "De Masi: Disoccupati ribellatevi: offrite lavoro gratis sul web," il manifesto, March 24, 2017, https://ilmanifesto.it/de-masi-disoccupati-ribellatevi-offrite-lavorogratis-sul-web/ (Accessed on July 21, 2017).

42. Sergio Bologna and Andrea Fumagalli, eds., Il lavoro autonomo di seconda generazione. Scenari del postfordismo in Italia (Milan, 1997).

43. In July 2017, Maurizio Landini left the Federazione Italiana Operai Meccanici (FIOM) and joined the General Secretary of the CGIL.

44. Dario Di Vico, "Landini: In fabbrica tanti con M5S. Il web conta e ci attrezzeremo," Il Corriere della Sera, February 6, 2017, http://www.corriere.it/politica/17_febbraio_07/landini-infabbrica-tanti-m5s-1eb32da8-ecb0-11e6-b0dc-72bd53481b5d.shtml (Accessed on July 21, 2017). (Il Corriere della Sera is a daily newspaper).

45. Marco Tarchi, Italia populista. Dal qualunquismo a Beppe Grillo (Bologna, 2015), 351.

46. Gad Lerner, Operai, Television report in six episodes broadcast between May 7 and June 12, 2017, http://www.raiplay.it/programmi/operai/puntate (Accessed on July 25, 2017).

47. Lerner, Operai.

48. Luigi Campagna et al., Le persone e la fabbrica. Una ricerca sugli operai Fiat Chrysler in Italia (Milan, 2015). 